\title{
Reitu Me Reipae
}

The book "The Tail of the Fish" was publised in 1968 and written by a Te Aupouri kuia, Matire Kereama (nee: Hoeft) of the far north of Aotearoa, New Zealand. I grew up with this book as my grandmother would read the stories to me at bedtime. Although my comprehension of each story was very vague and unrelatable to my life at that time, today, I find myself totally absorbed by the historical content and knowledge encapsulated in each chapter.

I completed a Masters of Applied Indigenous Knowledge at Te Wananga o Aotearoa in 2017, entitled; Tales of the singing fish: He tangi wairua. I compsed twelve waiata (Maori songs) of which ten of the waiata was information extracted from ten chapters of the book. The other two waiata were composed specifically for my people of the Te Rarawa tribe, namely, Ahipara.

The story of Reitu and Reipae were ancestors of the Tainui people located at Tuakau. Far off at Whangape in the Hokianga lived a man named Üeoneone. He had heard the beauty of these two women and wanted them for himself so he sent his Kārearea, a giant bird to fetch one of the women from the Waikato region. When the women saw the great bird, they ran up to it and to their amazement, the bird spokle to them. It told them it had come for Reitu, who at once said, "yes, I will go with you". The bird then said, "come and sit on my back". Reitu obeyed the birds command and as Reipae watched her sister climb up onto the huge bird, she also begged for the bird to take her too. 
When they arrived to the Northern Wairoa near Dargaville, the younger sister Reipae asked to be let down to rest awhile. The bird landed near a village where Reipae alighted and then flew off agian with Reitu. History tells us how Reipae was found and taken to the chief of the district whose wife and the great ancester of the Ngāti Whātua tribe she became. Reitu reached her destination safely to find Üeoneone waiting anxiously for her. Reitu became the great-great grandmother of the northern tribes of Aotearoa, New Zealand.

Ko Retiu te wāhine

Ko Reipae te tuahine

Ka moe i a Üeoneone

Ka puta ko mātou

O te Hiku o te Ika

Ảnei ā Te Rarawa e

Ka moe a Kōkako

Ki a Hinepare o Waikato

Ka puta ko Reitu me Reipae

Kei Tuakau e noho ana

Ka tae mai te keakea

Te manu rangatira o Ūeoneone

Ka heke mai ā Reipae i te manu e Ki Ngāti Whātua ka puta te iwi e Ka tae a Reitu ki te taitama ā tāne Ki te rohe o Ngāti Hāua ki Whangapē Tìhei Mauri Mate 